\title{
United States counties with Black Lives Matter protests had larger Democratic swings in the 2020 presidential election
}

\author{
Drew M Thomas ${ }^{\mathrm{a}}$

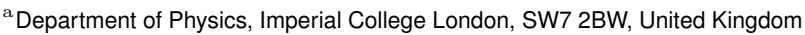 \\ This typescript was compiled on February 20, 2022.
}

\begin{abstract}
Media commentary has proposed that election-year Black Lives Matter (BLM) protests, especially riots, drove voters, especially Hispanic voters, away from Democratic candidate Joe Biden in the 2020 US presidential election. I test such hypotheses with county-level regression models of 2016-to-2020 one-party swing towards the Democratic presidential candidate, using the presence and intensity of BLM non-riot protests and riots as regressors, controlling for state and background factors. The models (generalized additive models) that control most aggressively for background factors find positive associations between BLM protests and Democratic swing: counties with non-riot BLM protests swung towards Biden by 0.3-0.4 percentage points more, and counties with BLM-associated riots swung towards Biden by 0.4 points more. Counties with relatively many Hispanic voting-age citizens swung similarly towards Biden after nonriot BLM protests, but swung less towards Biden after BLM riots. Inasmuch as these results reflect causal effects of BLM protests, the protests enhanced the Democratic swing but were not electorally decisive. My generalized additive models suggest that BLM protests in 2020 flipped only Arizona and possibly Georgia, narrowly, for Biden.
\end{abstract}

elections | president | Black Lives Matter

\section{B} efore, during, and after the US presidential election of 2020, media commentary discussed the prospect of Black Lives Matter (BLM) protests depressing support for Democratic candidate Joe Biden. Freddy Gray, editor of The Spectator's US website, wrote in August 2020 that "[t]he Black Lives Matter movement could sink the Democrats and ensure Donald Trump's reelection" (1). On the eve of the last day of voting Ann Coulter suggested in a radio interview that "militant, obnoxious, violent" "Black Lives Matter and Antifa" "riots" could provoke a Democratic loss (2). A New York Times report from the week after the election quoted voters who claimed to be driven towards or away from Biden by BLM (3). Postelection commentary raised the specific issues of BLM slogan "defund the police" (4, 5, 7-11) and of Latina and Latino voters reacting negatively to BLM protests $(6,7,12,13)$.

In this paper I test such anecdotes and punditry at a local level, presenting statistical analyses of the 2020 US presidential election's returns at the county (and countyequivalent - hereafter simply "county") level. The essential idea is to compare election results across counties that experienced differing levels of BLM protests between the killing of George Floyd and the end of voting in the 2020 election; a correlation between protest intensity and election results might be read as the average effect of the BLM protests on election results. Such a correlation might, of course, represent confounding by omitted variables rather than the true causal effect of BLM protests. To mitigate that problem I use regression models to apply a within-state difference-in-differences-like design: I correlate within-state variation in BLM protests' intensity with within-state changes from 2016 to 2020 in how Americans voted, controlling for county-level background factors such as population density and black share of the population.

\section{Data}

My dependent variable is the one-party Democratic swing: the Democratic vote share in the 2020 presidential election minus the Democratic vote share in the 2016 presidential election. Analyzing 2016-to-2020 swing instead of the vote share in 2020 controls for baseline levels of Democratic presidential support. I compute Democratic vote shares from the election returns recently published by Sharif Amlani and Carlos Algara (14) at the county level from 1872 through 2020 (15). That dataset excludes Alaska,

\section{Significance Statement}

Widespread Black Lives Matter protests in 2020 may have discouraged votes for Democrat Joe Biden in 2020's US presidential election. I test for such backlash with statistical models of changes in Democratic vote share from the 2016 presidential election to 2020. Controlling for background factors like unemployment, killings by police, and black share of the adult-citizen population, US counties with Black Lives Matter protests (including riots) shifted more, not less, towards Biden, suggesting that the protests encouraged voting for Biden locally, perhaps enough to win Biden Arizona. However, counties where more voting-eligible adults were Hispanic swung less towards Biden after Black Lives Matter-associated riots.

DMT translated ambient media commentary into specific research questions, for mulated the research approach, accessed the data, cleaned and linked the data, performed the statistical analyses, and wrote the paper.

The author declares no conflict of interest.

${ }^{1}$ Email: dmt107@imperial.ac.uk 
and I further exclude the District of Columbia because there the dataset has only aggregate results for the entire District, not for intra-District subregions.

I build measures of BLM-protest intensity from the 14 November dataset of the US Crisis Monitor (UCM) project of the Armed Conflict Location \& Event Data Project and Bridging Divides Initiative (16). The dataset comprises 17,328 dated records of "Protests", "Riots", "Strategic developments", "Violence against civilians", or "Battles", each record including the event's location's latitude and longitude. I identify 9695 records of BLM actions by the presence of the string "BLM: Black Lives Matter" in a record's ASSOC_ACTOR_1 field, then sort them according to the UCM's "Protests" versus "Riots" distinction into 9093 records of non-riot protests and 597 records of riots (alongside 5 records of "Strategic developments" that I discard). Setting aside 83 records of BLM events dated after 3 November 2020, I map the remaining 9607 BLM records' longitudes and latitudes to counties using the US Census Bureau's 2019 TIGER/Line ${ }^{\circledR}$ counties-andequivalent shapefile (17), and count the number of BLM non-riot protests and riots in every county. Dividing each county's counts by total population in thousands produces two explanatory variables: BLMPPT, the number of BLM non-riot protests per thousand, and BLMRPT, the number of BLM-associated riots per thousand.

I link the BLM-event rates and results of the 2016 and 2020 elections to demographic variables, most from the American Community Survey (ACS). Table 1 catalogues the demographic variables I derive from the "Selected Social Characteristics in the United States" (18), "Selected Economic Characteristics" (19), and "Age and Sex" (20) tables of 5-Year Estimates of the 2015-2019 ACS, as well as the 2015-2019 ACS's Citizen Voting Age Population (CVAP) Special Tabulation of counties' total CVAPs, single-race CVAPs, and multiracial CVAPs, (21), which I use as numerators to compute racial CVAP shares, and adult populations, which I use as denominators when computing shares of the adult population.

The remaining variables (table 2) incorporate data from non-ACS sources. Newly released 2020 Decennial Census redistricting data (22) supply the total population in every county, which serve as denominators when computing rates (of e.g. COVID-19 infection) in the whole population. Dividing those total-population estimates by the TIGER/Line® shapefile's land areas gives each county's population density in people per square kilometre; since counties' population densities are positive and very right-skewed, I log-transform them. I compute 2016-2019 growth and 2019-2020 growth in per capita personal income from the US Bureau of Economic Analysis's county-level personal-income time series (23); take the April 2020 unemployment rate from the US Bureau of Labor Statistics's Local Area Unemployment Statistics (24); retrieve percentages of counties' populations who were evangelical Protestants, mainline Protestants, Catholics,
Orthodox Christians, Church of Jesus Christ of Latterday Saints adherents, Conservative and Orthodox Jews, Reform and Reconstructionist Jews, Hindus, Muslims, and Buddhists from the 2010 US Religion Census of the Association of Statisticians of American Religious Bodies (25); compute county-level rates of COVID-19 cases and COVID-19 deaths from the counts in the COVID-19 Data Repository of Johns Hopkins University's Center for Systems Science and Engineering (26); and count killings by police of black people and of non-black people (counting killed people of unknown race as non-black) since 20 January 2017 (the day of Donald Trump's inauguration) in Mapping Police Violence's dataset (27), translating each killing's ZIP code to a county using the US Census Bureau's ZCTA to County Relationship File (28) where necessary. Retrieving the Defense Manpower Data Center's Defense Casualty Analysis System's records of US military personnel killed in Operations Enduring Freedom (29), Iraqi Freedom (30), New Dawn (31), Inherent Resolve (32), or Freedom's Sentinel (33) during the administrations of George W. Bush and Barack Obama, I count miltary fatalities assigned to each home county and normalize each US county's military fatalities by its population in millions. Finally, I use counties' longitudes and latitudes from the TIGER/LINE® shapefile to compute measures of spatial autocorrelation, and use each county's de-meaned latitude (latitude minus the CVAP-weighted, state-level mean of latitude) as a regressor to ameliorate spatial autocorrelation. I do not use longitude as a regressor because it is less associated with Democratic swing than latitude, and experimenting with it in preliminary modelling revealed that using longitude could exacerbate the spatial autocorrelation of some models' residuals.

\section{Results}

A. Linear-regression models. My dataset encompasses 3111 of the 3112 counties in the 49 US states other than Alaska; I omit the remaining county, Kalawao County in Hawaii (population 82 in 2020), for want of income and unemployment data. According to the geolocated UCM dataset, 1427 (46\%) of the 3111 counties experienced a BLM non-riot protest, and $188(6 \%)$ experienced a riot involving BLM. Figure 1 presents more detail, plotting the Democratic swing against BLM-protest intensity by state and county. In an overwhelming majority of states, BLM protests correlated positively with Democratic swing.

Those correlations may not reflect the causal impact of BLM protests. Comparing counties only to other counties within the same state does eliminate confounding by statelevel variables such as state-wide electoral-administration policies and COVID-19 policies, but even within a state, counties with BLM protests may systematically differ from counties without protests in other ways that themselves influence Democratic swing. For example, urban counties might have swung more towards the Democratic Party 
Table 1. County-level demographic variables from the American Community Survey 5-Year Estimates.

\begin{tabular}{|c|c|c|c|}
\hline variable & mean & std. deviation & source(s) \\
\hline average household size & 2.51 & 0.269 & (18) \\
\hline education: $\%$ of population aged $25+$ with... & & & (18) \\
\hline ... less than high-school education & 13.1 & 6.3 & (18) \\
\hline ...high-school education & 34.2 & 7.2 & (18) \\
\hline ... graduate or professional degree & 7.7 & 4.4 & (18) \\
\hline veteran $\%$ of adult, civilian population & 8.7 & 2.6 & (18) \\
\hline disabled $\%$ of adult, non-institutionalized, civilian population & 16.0 & 4.4 & $(18)$ \\
\hline migration: $\%$ of population aged $1+$ who, a year ago, lived. . . & & & (18) \\
\hline ... in a different county in the same state & 4.22 & 2.27 & (18) \\
\hline ...overseas & 0.34 & 0.57 & (18) \\
\hline$\%$ of households with a broadband Internet connection & 75.4 & 8.8 & (18) \\
\hline employment status: $\%$ changepulation aged $16+\ldots$ & & & (19) \\
\hline ...employed in the civilian labour force & 55.05 & 8.24 & (19) \\
\hline ... unemployed in the civilian labour force & 2.96 & 1.30 & (19) \\
\hline ...employed in the armed forces & 0.29 & 1.55 & (19) \\
\hline industry: $\%$ of employed civilians aged $16+$ who worked in. & & & (19) \\
\hline ...primary industry & 6.5 & 7.3 & (19) \\
\hline ...construction & 7.5 & 2.4 & (19) \\
\hline ...manufacturing & 12.3 & 7.1 & (19) \\
\hline ...transportation, warehousing, utilities & 5.6 & 2.0 & (19) \\
\hline ... finance, insurance, real estate & 4.6 & 1.9 & (19) \\
\hline employer: $\%$ of employed civilians aged $16+$ who were. . & & & (19) \\
\hline ...government workers & 16.6 & 5.9 & (19) \\
\hline ... "[s]elf-employed in own not incorporated business" & 7.7 & 3.9 & (19) \\
\hline median household income in thousands of dollars & 53.3 & 14.1 & (19) \\
\hline $\log _{2}$ of (mean household income $\div$ median household income) & 0.40 & 0.116 & (19) \\
\hline age and sex: $\%$ of adult population which was... & & & $(20,21)$ \\
\hline ... male and aged $18-24$ & 5.90 & 2.31 & $(20,21)$ \\
\hline$\ldots$ female and aged $18-24$ & 5.28 & 2.21 & $(20,21)$ \\
\hline ... male and aged $25-34$ & 7.91 & 2.00 & $(20,21)$ \\
\hline ... female and aged $25-34$ & 7.33 & 1.58 & $(20,21)$ \\
\hline$\ldots$ male and aged $75-84$ & 3.31 & 1.09 & $(20,21)$ \\
\hline$\ldots$ female and aged $75-84$ & 4.06 & 1.08 & $(20,21)$ \\
\hline ...male and aged $85+$ & 1.04 & 0.50 & $(20,21)$ \\
\hline ... female and aged $85+$ & 1.87 & 0.78 & $(20,21)$ \\
\hline race: $\%$ of citizen voting-age population identifying as. . & & & $(21)$ \\
\hline ..."Asian Alone" & 0.98 & 2.32 & (21) \\
\hline ... "Black or African American Alone" & 9.02 & 14.42 & $(21)$ \\
\hline ... "Hispanic or Latino" & 6.59 & 11.99 & (21) \\
\hline ... "American Indian or Alaska Native Alone" & 1.50 & 6.15 & (21) \\
\hline ...multiracial & 1.37 & 1.41 & (21) \\
\hline
\end{tabular}

"\% of" denotes "percentage of". Primary industry comprises agriculture, forestry, fishing, hunting, and mining. 


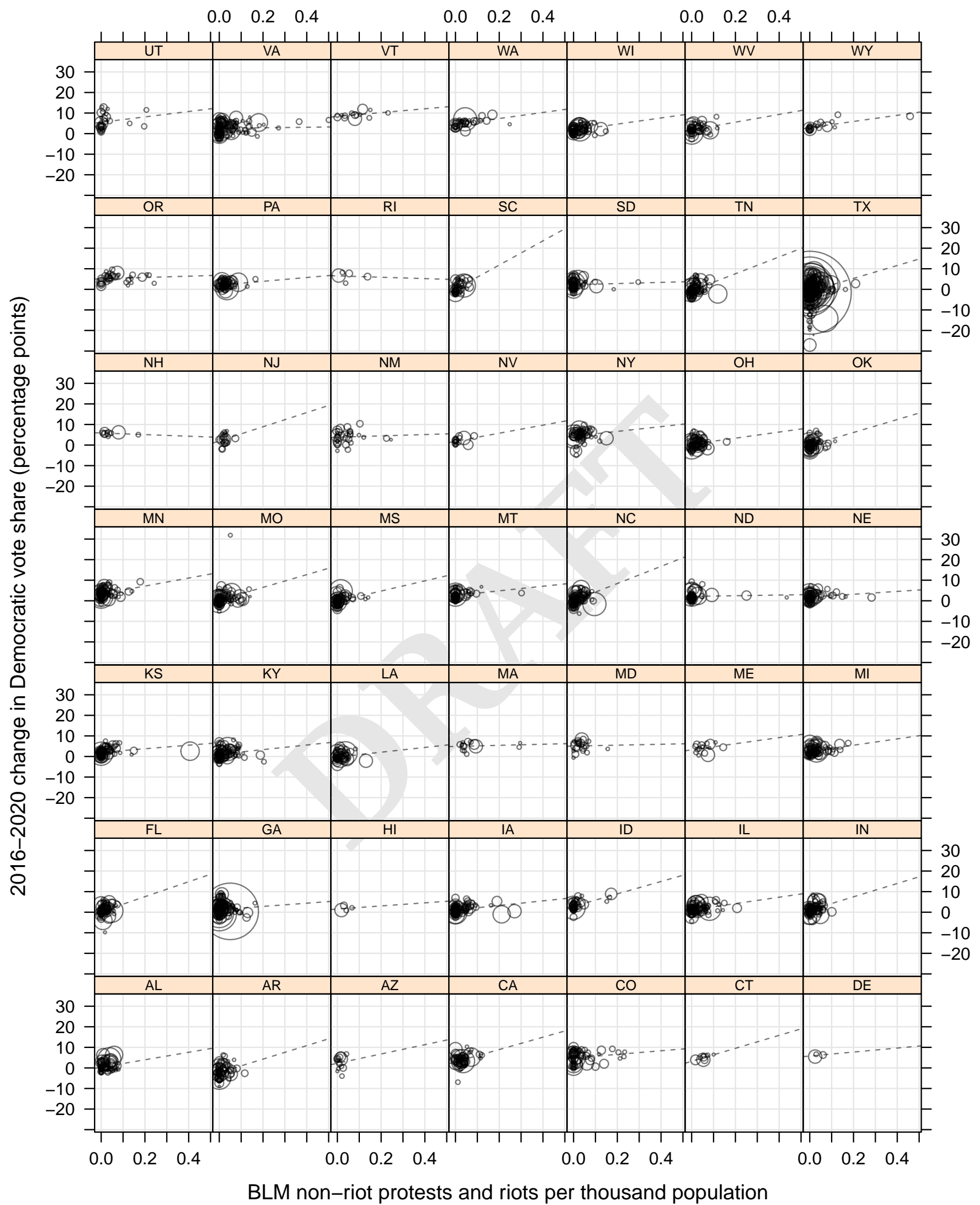

Fig. 1. Democratic swings from the 2016 to the 2020 presidential election and intensity of BLM protests ( $N=3111$ counties within 49 states). Points' areas are proportional to citizen voting-age population (CVAP). The county of highest protest intensity (Williamsburg, Virginia; 1.56 BLM protests/riots per thousand) is cropped out as an outlier. 
Table 2. County-level regressors from sources other than the American Community Survey.

\begin{tabular}{|c|c|c|c|}
\hline variable & mean & SD & source(s) \\
\hline $\log _{2}$ of population density in $\mathrm{km}^{-2}$ & 4.13 & 2.54 & $(17,22)$ \\
\hline income growth in percent, 2016-2019 & 11.1 & 6.6 & (23) \\
\hline income growth in percent, 2019-2020 & 8.3 & 5.2 & (23) \\
\hline mean unemployment rate in percent .. & & & (24) \\
\hline . . . in April 2020 & 12.4 & 5.2 & (24) \\
\hline ... from April through August 2020 & 9.1 & 3.3 & (24) \\
\hline ... from April through October 2020 & 8.1 & 2.9 & (24) \\
\hline religion: \% of popul'n identified as... & & & (25) \\
\hline ... evangelical Protestant & 23.23 & 16.32 & (25) \\
\hline ... mainline Protestant & 11.58 & 10.10 & (25) \\
\hline ... Catholic & 12.39 & 13.50 & (25) \\
\hline ... Orthodox Christian & 0.06 & 0.31 & $(25)$ \\
\hline ... of the Church of Latter-day Saints & 2.17 & 8.58 & (25) \\
\hline ... Conservative/Orthodox Jewish & 0.06 & 0.55 & (25) \\
\hline ...Reform/Reconstructionist Jewish & 0.05 & 0.21 & $(25)$ \\
\hline$\ldots$ Hindu & 0.06 & 0.35 & (25) \\
\hline ....Muslim & 0.23 & 1.06 & $(25)$ \\
\hline ... Buddhist & 0.08 & 0.47 & (25) \\
\hline COVID-19: cumulative... & & & $(22,26)$ \\
\hline ....cases per hundred, 25 May & 0.28 & 0.56 & $(22,26)$ \\
\hline ... deaths per thousand, 25 May & 0.12 & 0.27 & $(22,26)$ \\
\hline ... cases per hundred, 4 September & 1.52 & 1.34 & $(22,26)$ \\
\hline ... deaths per thousand, 4 Sep. & 0.36 & 0.48 & $(22,26)$ \\
\hline .... cases per hundred, 3 November & 2.97 & 1.84 & $(22,26)$ \\
\hline ... deaths per thousand, 3 Nov. & 0.60 & 0.64 & $(22,26)$ \\
\hline police killings per 10,000 popul'n of. . . & 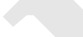 & & $(22,27,28)$ \\
\hline ... black people as of 25 May & 0.02 & 0.12 & $(22,27,28)$ \\
\hline ... non-black people as of 25 May & 0.11 & 0.39 & $(22,27,28)$ \\
\hline ... black people as of 4 September & 0.02 & 0.12 & $(22,27,28)$ \\
\hline ... non-black people as of 4 Sep. & 0.12 & 0.40 & $(22,27,28)$ \\
\hline ... black people as of 3 November & 0.02 & 0.12 & $(22,27,28)$ \\
\hline ... non-black people as of 3 Nov. & 0.13 & 0.40 & $(22,27,28)$ \\
\hline de-meaned latitude in degrees north & 0.11 & 1.34 & (17) \\
\hline military fatalities per $10^{6}$ popul'n. . & & & $(22,29-33)$ \\
\hline ... during the Bush administration & 18.1 & 46.8 & $(22,29-33)$ \\
\hline ... during the Obama administration & 5.6 & 17.4 & $(22,29-33)$ \\
\hline
\end{tabular}

"SD", "popul'n", "\% of", and "income growth" denote "standard deviation", "population", "percentage of", and "growth in per capita personal income" respectively. and been more likely to host BLM protests in response to higher rates of police killings, rather than BLM protests causing more of a swing towards the Democratic Party.

To mitigate the remaining confounding, I fit linearregression models that use variables summarized in $\$ 1$ as covariates: the ACS-based demographic variables in table 1; the base-2 logarithm of population density; 20162019 growth in per capita personal income; April 2020 unemployment rate, complementing the ACS's long-term unemployment rate; shares of the population in different religious denominations; cumulative COVID-19 cases per hundred as of 25 May; cumulative COVID-19 deaths per thousand as of 25 May; police killings of black people and non-black people per 10,000 population as of 25 May; deaths of military personnel in Global War on Terrorism operations per million home-county population, during the Bush administration and the Obama administration respectively; and de-meaned latitude. I use 25 May 2020 as a cutoff for counting police killings and COVID-19 cases and deaths, and April 2020 as a cutoff for short-term unemployment rates, to screen out any indirect effect on voting of BLM protests via BLM protests' potential effect on COVID-19 spread, police killings, and unemployment.

Table 3 compares a model with those controls (model II) to a naive model (model I) with only state-level dummy variables as controls. At face value, the naive model would suggest a large impact on a county's voting of a BLM non-riot protest — an enhancement to 2016-to-2020 Democratic swing of 2.73 percentage points — versus a negligible impact from a BLM riot (a strengthening of the Democratic swing by 0.02 percentage points). Model II, by contrast, with its full array of demographic controls, finds a smaller association between BLM non-riot protests and Democratic swing: all else equal, counties with BLM non-riot protests swung 0.51 percentage points harder towards the Democratic Party in 2020. Interestingly, model II's estimate for riots is higher than its estimate for non-riots, albeit not to a statistically significant extent: counties with BLM-associated riots swung 0.73 percentage points harder towards the Democratic Party.

Model II, and the subsequent models, also quantify the partial (all else equal) associations between Democratic swing and other variables. Table 3 presents these associations for individual non-ACS variables. Denser counties swung harder towards the Democrat than less-dense counties, counties with more pre-pandemic income growth and higher during-pandemic unemployment swung less towards the Democrat, and (perhaps most obscurely) so did northern counties compared to southern counties in the same state. Rates of COVID-19 deaths, and of military fatalities under Bush and Obama, had no statistically significant associations with Democratic swing.

Using pre-protest levels of COVID-19 spread, killings by police, and unemployment in model II avoids the problem of controlling for a post-treatment variable. If one expects BLM protests to influence COVID-19 spread, 
Table 3. Weighted least-squares linear regressions of 2016-2020 Democratic swing (2020 Democratic vote share in percent minus 2016 Democratic vote share in percent) versus BLM-protest intensity and other regressors.

\begin{tabular}{|c|c|c|c|c|c|c|c|c|}
\hline \multirow[b]{2}{*}{ regressor or model-summary statistic } & \multicolumn{8}{|c|}{ coefficients/statistics from linear regression } \\
\hline & $\mathrm{I}$ & II & III & IV & $\mathrm{V}$ & $\mathrm{VI}$ & VII & VIII \\
\hline presence of BLM non-riot protest in county & $\begin{array}{c}2.73 \\
(0.19)\end{array}$ & $\begin{array}{c}0.51 \\
(0.14)\end{array}$ & $\begin{array}{c}0.49 \\
(0.14)\end{array}$ & $\begin{array}{c}0.48 \\
(0.14)\end{array}$ & $\begin{array}{c}0.54 \\
(0.14)\end{array}$ & $\begin{array}{c}0.61 \\
(0.15)\end{array}$ & $\begin{array}{c}0.58 \\
(0.15)\end{array}$ & $\begin{array}{c}0.58 \\
(0.15)\end{array}$ \\
\hline presence of BLM riot in county & $\begin{array}{c}0.02 \\
(0.13)\end{array}$ & $\begin{array}{c}0.73 \\
(0.11)\end{array}$ & $\begin{array}{c}0.67 \\
(0.11)\end{array}$ & $\begin{array}{c}0.70 \\
(0.11)\end{array}$ & $\begin{array}{c}0.71 \\
(0.11)\end{array}$ & $\begin{array}{c}0.77 \\
(0.11)\end{array}$ & $\begin{array}{c}0.71 \\
(0.11)\end{array}$ & $\begin{array}{c}0.75 \\
(0.11)\end{array}$ \\
\hline ACS-based demographic variables & no & yes & yes & yes & yes & yes & yes & yes \\
\hline religious denominations' population shares (\%) & no & yes & yes & yes & yes & yes & yes & yes \\
\hline $\log _{2}$ population density & & $\begin{array}{c}0.21 \\
(0.05)\end{array}$ & $\begin{array}{c}0.25 \\
(0.05)\end{array}$ & $\begin{array}{c}0.23 \\
(0.05)\end{array}$ & $\begin{array}{c}0.22 \\
(0.05)\end{array}$ & $\begin{array}{c}0.20 \\
(0.05)\end{array}$ & $\begin{array}{c}0.25 \\
(0.05)\end{array}$ & $\begin{array}{c}0.23 \\
(0.05)\end{array}$ \\
\hline 2016-2019 growth in per capita personal income (\%) & & $\begin{array}{l}-0.05 \\
(0.01)\end{array}$ & $\begin{array}{l}-0.05 \\
(0.01)\end{array}$ & $\begin{array}{l}-0.05 \\
(0.01)\end{array}$ & $\begin{array}{l}-0.04 \\
(0.01)\end{array}$ & $\begin{array}{l}-0.05 \\
(0.01)\end{array}$ & $\begin{array}{l}-0.05 \\
(0.01)\end{array}$ & $\begin{array}{l}-0.05 \\
(0.01)\end{array}$ \\
\hline 2019-2020 growth in per capita personal income (\%) & & & & & $\begin{array}{c}0.11 \\
(0.02)\end{array}$ & & & \\
\hline de-meaned latitude $\left({ }^{\circ} \mathrm{N}\right)$ & & $\begin{array}{c}0.27 \\
(0.03)\end{array}$ & $\begin{array}{c}0.25 \\
(0.03)\end{array}$ & $\begin{array}{c}0.27 \\
(0.03)\end{array}$ & $\begin{array}{c}0.24 \\
(0.03)\end{array}$ & $\begin{array}{c}0.27 \\
(0.03)\end{array}$ & $\begin{array}{c}0.25 \\
(0.03)\end{array}$ & $\begin{array}{c}0.27 \\
(0.03)\end{array}$ \\
\hline military fatalities per million, Bush era & & $\begin{array}{c}0.002 \\
(0.002)\end{array}$ & $\begin{array}{c}0.002 \\
(0.002)\end{array}$ & $\begin{array}{c}0.002 \\
(0.002)\end{array}$ & $\begin{array}{c}0.002 \\
(0.002)\end{array}$ & $\begin{array}{c}0.002 \\
(0.002)\end{array}$ & $\begin{array}{c}0.002 \\
(0.002)\end{array}$ & $\begin{array}{c}0.002 \\
(0.002)\end{array}$ \\
\hline military fatalities per million, Obama era & & $\begin{array}{c}0.000 \\
(0.004)\end{array}$ & $\begin{array}{c}0.000 \\
(0.004)\end{array}$ & $\begin{array}{c}0.000 \\
(0.004)\end{array}$ & $\begin{array}{c}0.001 \\
(0.004)\end{array}$ & $\begin{array}{c}0.001 \\
(0.004)\end{array}$ & $\begin{array}{c}0.001 \\
(0.004)\end{array}$ & $\begin{array}{c}0.001 \\
(0.004)\end{array}$ \\
\hline unemployment rate in April 2020 (\%) & & $\begin{array}{l}-0.03 \\
(0.02)\end{array}$ & & & $\begin{array}{l}-0.03 \\
(0.02)\end{array}$ & $\begin{array}{l}-0.03 \\
(0.02)\end{array}$ & & \\
\hline cumulative COVID-19 case rate as of 25 May (\%) & & $\begin{array}{c}0.04 \\
(0.13)\end{array}$ & & & $\begin{array}{c}0.06 \\
(0.13)\end{array}$ & $\begin{array}{c}0.04 \\
(0.13)\end{array}$ & & \\
\hline total COVID-19 deaths per thousand as of 25 May & & $\begin{array}{c}0.19 \\
(0.19)\end{array}$ & & & $\begin{array}{c}0.10 \\
(0.19)\end{array}$ & $\begin{array}{c}0.19 \\
(0.19)\end{array}$ & & \\
\hline police-killed black people per 10,000 as of 25 May & & $\begin{array}{l}1.20 \\
(0.70)\end{array}$ & & & $\begin{array}{c}1.22 \\
(0.70)\end{array}$ & $\begin{array}{l}1.26 \\
(0.71)\end{array}$ & & \\
\hline police-killed non-black people per 10,000 as of 25 May & & $\begin{array}{c}0.54 \\
(0.29)\end{array}$ & & & $\begin{array}{c}0.53 \\
(0.29)\end{array}$ & $\begin{array}{c}0.52 \\
(0.29)\end{array}$ & & \\
\hline mean unemployment rate, April-October 2020 (\%) & & & $\begin{array}{l}-0.12 \\
(0.03)\end{array}$ & & & & $\begin{array}{l}-0.12 \\
(0.03)\end{array}$ & \\
\hline cumulative COVID-19 case rate as of 3 November (\%) & & & $\begin{array}{c}0.12 \\
(0.05)\end{array}$ & & & & $\begin{array}{c}0.12 \\
(0.05)\end{array}$ & \\
\hline total COVID-19 deaths per thousand as of 3 November & & & $\begin{array}{l}-0.02 \\
(0.13)\end{array}$ & & & & $\begin{array}{l}-0.01 \\
(0.13)\end{array}$ & \\
\hline police-killed black people per 10,000 as of 3 November & & & $\begin{array}{c}1.32 \\
(0.67)\end{array}$ & & & & $\begin{array}{l}1.37 \\
(0.67)\end{array}$ & \\
\hline police-killed non-black people per 10,000 as of 3 November & & & $\begin{array}{c}0.49 \\
(0.27)\end{array}$ & & & & $\begin{array}{c}0.47 \\
(0.27)\end{array}$ & \\
\hline mean unemployment rate, April-August 2020 (\%) & & & & $\begin{array}{l}-0.09 \\
(0.02)\end{array}$ & & & & $\begin{array}{l}-0.08 \\
(0.02)\end{array}$ \\
\hline cumulative COVID-19 case rate as of 4 September (\%) & & & & $\begin{array}{c}0.18 \\
(0.07)\end{array}$ & & & & $\begin{array}{l}0.18 \\
(0.07)\end{array}$ \\
\hline total COVID-19 deaths per thousand as of 4 September & & & & $\begin{array}{l}0.18 \\
(0.15)\end{array}$ & & & & $\begin{array}{c}0.19 \\
(0.15)\end{array}$ \\
\hline police-killed black people per 10,000 as of 4 September & & & & $\begin{array}{l}1.18 \\
(0.68)\end{array}$ & & & & $\begin{array}{l}1.23 \\
(0.68)\end{array}$ \\
\hline police-killed non-black people per 10,000 as of 4 September & & & & $\begin{array}{l}0.55 \\
(0.28)\end{array}$ & & & & $\begin{array}{l}0.53 \\
(0.28)\end{array}$ \\
\hline BLMPPT, BLM non-riot protests per thousand & & & & & & $\begin{array}{l}-2.6 \\
(1.6)\end{array}$ & $\begin{array}{l}-2.5 \\
(1.6)\end{array}$ & $\begin{array}{l}-2.7 \\
(1.6)\end{array}$ \\
\hline BLMRPT, BLM riots per thousand & & & & & & $\begin{array}{l}-5.6 \\
(7.6)\end{array}$ & $\begin{array}{l}-4.4 \\
(7.5)\end{array}$ & $\begin{array}{l}-4.9 \\
(7.5)\end{array}$ \\
\hline unadjusted $R^{2}(\%)$ & 61.2 & 85.4 & 85.6 & 85.5 & 85.6 & 85.5 & 85.6 & 85.6 \\
\hline adjusted $R^{2}(\%)$ & 60.5 & 84.9 & 85.1 & 85.0 & 85.1 & 84.9 & 85.1 & 85.0 \\
\hline Moran's $I \times 1000$ & 51.6 & 26.6 & 25.9 & 25.7 & 28.3 & 27.1 & 26.4 & 26.1 \\
\hline standardized Moran's $I$ & 85.2 & 44.2 & 43.1 & 42.6 & 46.9 & 44.9 & 43.8 & 43.4 \\
\hline
\end{tabular}

$N=3111$ US counties, each weighted by CVAP. Parenthetical values are standard errors uncorrected for spatial autocorrelation. All regressions exclude the intercept but include 49 dummy variables for states ("state fixed effects" in econometric jargon). 
police killings, or unemployment, then one may dispute using post-protest levels of COVID-19 or police killings as a control, because the model might then confuse the impact of BLM protests on voting with the impacts of COVID-19, of police killings, or of unemployment.

One could instead believe that BLM protests had a negligible impact on COVID-19 spread, police killings, and unemployment, and that police killings and the spread of COVID-19 remained relevant to voters after 25 May. In that case it would be more appropriate to use police killings, unemployment, and COVID-19's spread up to 3 November, the last day of voting, as controls. Model III addresses that view by using cumulative police-killing rates and COVID-19 case and death rates through 3 November, not rates through 25 May, and average unemployment rates from April 2020 through October 2020.

Substituting more-recent rates of COVID-19 cases and deaths, police killings, and election-year unemployment switches the sign of Democratic swing's association with COVID-19 deaths, so that deaths become associated with a weaker Democratic swing, not a stronger swing; scarcely affects swing's positive association with killings by police; strengthens swing's negative association with unemployment; but leaves Democratic swing's associations with BLM protests much as they were before (non-riot protests and riots accompanying a bigger Democratic swing of 0.4 0.7 percentage points).

Model IV addresses early voting. Police killings, COVID-19 deaths, COVID-19 infections, and unemployment in November could not influence someone who voted in September or October. It may therefore be more appropriate to use measures of COVID-19, police killings, and unemployment taken before early voting began. The earliest date when votes might have been made is 4 September (34), when the first postal ballots were posted to eligible residents of North Carolina (34-36), so model IV uses police killings, COVID-19 cases, and COVID-19 deaths through 4 September, and unemployment from April through August as controls. These changes in cutoff dates have little effect on the BLM-related variables.

Models II-IV use personal-income growth from only 2016 to 2019, omitting personal-income growth from 2019 to 2020, again to avoid conditioning on a post-treatment variable (the BLM protests of 2020's second half might have influenced average personal income in 2020). To test whether including 2019-2020 growth in personal income affects the headline results, model V augments model II by adding 2019-2020 growth as a regressor. Alongside the other controls, 2019-2020 personal-income growth correlates positively with Democratic swing; on average, 9 additional percentage points of election-year growth accompany an extra percentage point of swing towards Biden. However, adding 2019-2020 growth to the regression makes little difference to the other regressors, even 2016-2019 personal-income growth. The associations between BLM protests and Democratic swing re- main virtually the same, and I omit 2019-2020 growth from subsequent models as a potential post-treatment variable of minimal relevance to the results of interest.

The measures of BLM activity in the models so far have been crude, simply tallying whether or not a BLM event occurred in a county. In practice the intensity of BLM protest varied greatly among counties that hosted protests. For example, Adams County, Colorado had a population of 519,572 and only one BLM protest, while Williamsburg, Virginia had a population of 15,425 and 24 BLM protests (one counted as riotous). Figure 1 illustrates this variation and suggests that counties with more BLM protests might have shown bigger Democratic swings than counties with fewer (but nonzero) BLM protests.

Model VI therefore elaborates on model II by adding two regressors: BLM non-riot protests per thousand population, and BLM riots per thousand population. Their coefficients are both negative, implying that while BLM protests were associated with stronger Democratic swings, there may have been negative returns on more-intense protest, although the negative coefficients are estimated imprecisely and statistically insignificant. Models VII and VIII repeat the exercise of using different cutoff dates for counting COVID-19 cases, COVID-19 deaths, and police killings. The different cutoffs have similar effects on model VI to those they had on model II, perturbing the BLM-related coefficients only slightly.

B. Generalized additive models. The linear-regression models all show positive associations between BLM nonriot protests and Democratic swing, and the fully controlled models all show similar positive associations between BLM riots and Democratic swing. However, those models have two problems. First, the models have highly statistically significant Moran's $I$ statistics, so each model's residuals have discernible spatial autocorrelation. That is, after adjusting for all of the BLM and control variables, the remaining unaccounted-for variation in Democratic swing shows patterns across space. That violates the linear-regression method's assumption of independently distributed residuals, and means that the standard errors in table 3 are likely too small. Second, the models assume without justification that, all else equal, every relationship between a regressor and Democratic swing is linear.

To ameliorate both problems, I fit more-flexible models known as generalized additive models (GAMs), which relax the assumption that regressors have straight-line relationships to Democratic swing. By allowing for nonlinear relationships, GAMs immediately resolve the second problem with linear regressions. GAMs can also help with the first problem, spatial autocorrelation, because GAMs' greater flexibility allows them to fit data more closely, leaving less residual variation to be accounted for by simple proximity.

Models IX, X, and XI are GAMs that use the same 
Table 4. Weighted generalized additive models of 2016-2020 Democratic swing (2020 Democratic vote share in percent minus 2016 Democratic vote share in percent) versus BLM-protest intensity and other regressors.

\begin{tabular}{|c|c|c|c|c|c|c|}
\hline \multirow[b]{2}{*}{ regressor or model-summary statistic } & \multicolumn{6}{|c|}{ coefficients/statistics from GAM } \\
\hline & IX & $\mathrm{X}$ & $\mathrm{XI}$ & XII & XIII & XIV \\
\hline $\begin{array}{l}\text { any BLM non-riot protest in county } \\
\text { any BLM riot in county }\end{array}$ & $\begin{array}{c}0.39 \\
(0.13) \\
0.40 \\
(0.11)\end{array}$ & $\begin{array}{c}0.34 \\
(0.13) \\
0.38 \\
(0.11)\end{array}$ & $\begin{array}{c}0.33 \\
(0.13) \\
0.40 \\
(0.11)\end{array}$ & $\begin{array}{c}0.44 \\
(0.14) \\
0.43 \\
(0.11)\end{array}$ & $\begin{array}{c}0.43 \\
(0.14) \\
0.41 \\
(0.11)\end{array}$ & $\begin{array}{c}0.42 \\
(0.14) \\
0.44 \\
(0.11)\end{array}$ \\
\hline $\begin{array}{l}\text { COVID-19 spread, killings by police, and mid-year unemployment as of... } \\
\text { BLMPPT, BLM non-riot protests per thousand } \\
\text { BLMPPT, BLM riots per thousand }\end{array}$ & 25 May & 3 Nov. & 4 Sep. & $\begin{array}{l}25 \text { May } \\
-1.8 \\
(1.5) \\
-5.4 \\
(6.9)\end{array}$ & $\begin{array}{l}3 \text { Nov. } \\
-2.2 \\
(1.4) \\
-4.6 \\
(6.9)\end{array}$ & $\begin{array}{l}4 \text { Sep. } \\
-2.2 \\
(1.4) \\
-4.7 \\
(6.9)\end{array}$ \\
\hline deviance explained (\%) & 80.6 & 80.8 & 81.0 & 80.5 & 80.7 & 81.0 \\
\hline adjusted $R^{2}(\%)$ & 79.2 & 79.3 & 79.6 & 79.1 & 79.3 & 79.6 \\
\hline Moran's $I \times 1000$ & 3.74 & 3.63 & 3.55 & 3.84 & 3.71 & 3.63 \\
\hline standardized Moran's $I$ & 7.24 & 7.10 & 6.93 & 7.44 & 7.23 & 7.07 \\
\hline
\end{tabular}

regressors as models II, III, and IV respectively, but fit nonlinear relationships between the non-BLM regressors and Democratic swing, instead of assuming linear relationships. Table 4 summarizes the relevant results. Compared to the linear regressions, models IX, X, and XI find weaker associations between Democratic swing and the presence of BLM protests, whether non-riots or riots. The associations do, however, remain positive and statistically significant at the conventional level $(2.5<t<3.8$, $\left.1.7 \times 10^{-4}<p<0.011\right)$, though the persistence of spatial autocorrelation casts some doubt on these signs of statistical significance. While the GAMs' (standardized) Moran's I statistics are far smaller than those of the linear regressions, they are themselves statistically significant, indicating some residual spatial autocorrelation.

Models XII, XIII, and XIV likewise adapt models VI, VII, and VIII as GAMs, incorporating the intensity of BLM riots and non-riot protests as regressors. The protest-intensity coefficients are smaller in the GAMs than in the linear regressions, consistent with the GAMs controlling more aggressively for non-BLM confounding factors, but the coefficients all remain negative.

All in all, the 6 GAMs (models IX-XIV) estimate that Democratic swing was stronger by about 0.4 percentage points in counties with a BLM protest, but at the margin additional protests accompanied slightly weaker swing.

C. Heterogeneity by race. Media commentary $(6,7,12$, 13) proposing that Latina and Latino voters had a particularly negative reaction to BLM protests supplies a further hypothesis to test: that the association between BLM protests and Democratic swing depends on counties' racial composition.

Models XV and XVI add regressors to models IX and XII representing the interaction of BLM protests' presence with racial shares of the CVAP (table 5). For example, models XV and XVI include an "any BLM riot $\times$ Native $\%$ of CVAP" regressor, which is a zero-or-one indicator of whether a county had a BLM riot, multiplied by the percentage of the citizen voting-age population that identifies as single-race American Indian. A positive coefficient for that regressor would imply that, holding everything else constant (including Asian, black, Hispanic, and multiracial shares of the CVAP), the pro-Democratic swing associated with having a BLM riot was stronger in counties where more of the CVAP were single-race American Indian. Analogously, one might expect the regressors interacting protest intensity with "Hispanic or Latino" CVAP share to be significantly negative, given media reports and opinion positing that such voters reacted notably negatively to BLM protests.

In fact, model XV estimates that only one of the Hispanic-share coefficients (table 5) is negative. A percentage-point increase in Hispanic CVAP share accompanied a weaker Democratic swing of $0.042 \pm 0.007$ points in counties with BLM riots, but a stronger Democratic swing of $0.011 \pm 0.010$ points in counties with BLM nonriot protests. It is also difficult to extract clear, consistent signals for other racial categories; for non-black categories the coefficients' standard errors tend to be larger. The only other clearly statistically significant $(|t|>3)$ estimate is for non-riot protests multiplied by black CVAP share, $-0.026 \pm 0.008(t=-3.1, p=0.0017)$, which is difficult to interpret in terms of a priori theory, especially alongside the statistically insignificant coefficient for BLM riots multiplied by black CVAP share.

In model XV the plain, not-interacted-with-race coefficients for the presence of BLM protest are larger than in model IX. In model IX, counties with a BLM non-riot protest swung more towards the Democrat by $0.39 \pm 0.13$ 
Table 5. Weighted generalized additive models of 2016-2020 Democratic swing (2020 Democratic vote share minus 2016 Democratic vote share, in percentage points) versus BLM protest intensity and BLM-protest intensity interacted with race, alongside other (not shown) regressors.

\begin{tabular}{|c|c|c|}
\hline \multirow[b]{2}{*}{ regressor or model-summary statistic } & \multicolumn{2}{|c|}{ coeffs. from GAM } \\
\hline & $\mathrm{XV}$ & $\mathrm{XVI}$ \\
\hline any BLM non-riot protest & $\begin{array}{c}0.65 \\
(0.22)\end{array}$ & $\begin{array}{c}0.90 \\
(0.25)\end{array}$ \\
\hline any BLM riot & $\begin{array}{c}1.25 \\
(0.25)\end{array}$ & $\begin{array}{c}0.52 \\
(0.35)\end{array}$ \\
\hline any BLM non-riot $\times$ Asian $\%$ of CVAP & $\begin{array}{r}-0.089 \\
(0.093)\end{array}$ & $\begin{array}{l}-0.146 \\
(0.095)\end{array}$ \\
\hline any BLM non-riot $\times$ black $\%$ of CVAP & $\begin{array}{l}-0.026 \\
(0.008)\end{array}$ & $\begin{array}{l}-0.023 \\
(0.009)\end{array}$ \\
\hline any BLM non-riot $\times$ Hispanic $\%$ of CVAP & $\begin{array}{c}0.011 \\
(0.010)\end{array}$ & $\begin{array}{c}0.013 \\
(0.011)\end{array}$ \\
\hline any BLM non-riot $\times$ Native $\%$ of CVAP & $\begin{array}{l}-0.061 \\
(0.024)\end{array}$ & $\begin{array}{l}-0.103 \\
(0.029)\end{array}$ \\
\hline any BLM non-riot $\times$ multiracial $\%$ of CVAP & $\begin{array}{l}0.038 \\
(0.101)\end{array}$ & $\begin{array}{l}-0.032 \\
(0.114)\end{array}$ \\
\hline any $\mathrm{BLM}$ riot $\times$ Asian $\%$ of CVAP & $\begin{array}{l}-0.057 \\
(0.025)\end{array}$ & $\begin{array}{l}-0.069 \\
(0.031)\end{array}$ \\
\hline any $\mathrm{BLM}$ riot $\times$ black $\%$ of CVAP & $\begin{array}{l}-0.004 \\
(0.007)\end{array}$ & $\begin{array}{l}-0.005 \\
(0.008)\end{array}$ \\
\hline any BLM riot $\times$ Hispanic $\%$ of CVAP & $\begin{array}{l}-0.042 \\
(0.007)\end{array}$ & $\begin{array}{r}-0.034 \\
(0.008)\end{array}$ \\
\hline any BLM riot $\times$ Native $\%$ of CVAP & $\begin{array}{c}0.126 \\
(0.059)\end{array}$ & $\begin{array}{c}0.375 \\
(0.259)\end{array}$ \\
\hline any BLM riot $\times$ multiracial $\%$ of CVAP & $\begin{array}{l}-0.099 \\
(0.101)\end{array}$ & $\begin{array}{c}0.134 \\
(0.141)\end{array}$ \\
\hline BLMPPT, BLM non-riot protests per 1000 & & $\begin{array}{l}-6.3 \\
(3.4)\end{array}$ \\
\hline BLMRPT, BLM riots per 1000 & & $\begin{array}{l}179 \\
(51)\end{array}$ \\
\hline BLMPPT $\times$ Asian $\%$ of CVAP & & $\begin{array}{l}-0.2 \\
(0.8)\end{array}$ \\
\hline BLMPPT $\times$ black $\%$ of CVAP & & $\begin{array}{l}-0.1 \\
(0.1)\end{array}$ \\
\hline BLMPPT $\times$ Hispanic $\%$ of CVAP & & $\begin{array}{l}-0.1 \\
(0.2)\end{array}$ \\
\hline BLMPPT $\times$ Native $\%$ of CVAP & & $\begin{array}{l}1.1 \\
(0.5)\end{array}$ \\
\hline BLMPPT $\times$ multiracial $\%$ of CVAP & & $\begin{array}{c}2.2 \\
(1.6)\end{array}$ \\
\hline BLMRPT $\times$ Asian $\%$ of CVAP & & $\begin{array}{l}12.8 \\
(5.7)\end{array}$ \\
\hline BLMRPT $\times$ black $\%$ of CVAP & & $\begin{array}{c}0.2 \\
(0.8)\end{array}$ \\
\hline BLMRPT $\times$ Hispanic $\%$ of CVAP & & $\begin{array}{l}-2.0 \\
(1.3)\end{array}$ \\
\hline BLMRPT $\times$ Native $\%$ of CVAP & & $\begin{array}{l}-38.7 \\
(37.3)\end{array}$ \\
\hline BLMRPT $\times$ multiracial $\%$ of CVAP & & $\begin{array}{l}-69.6 \\
(18.0)\end{array}$ \\
\hline deviance explained (\%) & 80.8 & 81.3 \\
\hline adjusted $R^{2}(\%)$ & 79.3 & 79.7 \\
\hline Moran's $I \times 1000$ & 3.86 & 3.35 \\
\hline standardized Moran's $I$ & 7.48 & 6.53 \\
\hline
\end{tabular}

$N=3111$ US counties, each weighted by CVAP. "\% of" denotes

"percentage of". Parenthetical values are standard errors uncorrected for spatial autocorrelation. Both GAMs exclude the intercept. Both

GAMs include 49 dummy variables for states; rates of killings by police, COVID-19 cases, and COVID-19 deaths as of 25 May; April

2020 unemployment rate; the ACS-based demographic variables;

religious denominations' population shares; $\log _{2}$ population density; 2016-2019 personal-income growth; de-meaned latitude; and Bush-era and Obama-era military-fatality rates. percentage points, and counties with a BLM riot swung more towards the Democrat by $0.40 \pm 0.11$ points. In model XV, by contrast, counties with a BLM non-riot protest swung more towards the Democrat by $0.65 \pm 0.22$ percentage points, and counties with a BLM riot swung more by $1.25 \pm 0.25$ points. The larger positive coefficients in model XV are mostly cancelled out by the negative contributions of the additional interacted-withrace regressors, but the former nonetheless imply that in overwhelmingly white counties, the average BLM protest, riotous or not, preceded a stronger swing towards the Democratic Party than model IX implies.

Model XVI elaborates model XV by adding regressors representing rates of BLM protests, and rates of BLM protests multiplied by racial CVAP shares. Like model XV, model XVI finds a small positive cofficient for Hispanic CVAP share interacted with the presence of non-riot BLM protests, and a more-significant negative coefficient for Hispanic CVAP share interacted with the presence of BLM riots. The two new regressors, which interact Hispanic CVAP share with BLM-protest intensities, are both negative but statistically insignificant. The 4 regressors' combined effect is modest, which I illustrate with the 66 majority-Hispanic counties in my dataset. On average, $66.9 \%$ of the CVAP in those counties was Hispanic, and those counties experienced 0.013 BLM non-riot protests per thousand population and $7.0 \times 10^{-5}$ BLM riots per thousand population; $36 \%$ of the counties had a BLM non-riot protest and 6\% had a BLM riot. By model XVI's estimates, the average majority-Hispanic county experiencing average (for majority-Hispanic counties) levels of BLM protests would show a Democratic swing 0.04 percentage points more than a county with zero Hispanic CVAP experiencing the same levels of BLM protests.

As for model XVI's implications for other racial categories, the coefficient estimates for multiracial CVAP shares are of varying sign and too statistically noisy to be readily interpretable; some of the Native CVAP shares' coefficients are also noisy and of varying sign, though the coefficient for Native CVAP share interacted with the presence of non-riot protests $(-0.103 \pm 0.029)$ may be statistically significant; black CVAP shares' coefficients are estimated much more precisely (their standard errors are far smaller) but are small, and only the "any BLM nonriot $\times$ black \% of CVAP" estimate might be statistically significant $(0.023 \pm 0.009$ percentage points less Democratic swing per black percent of CVAP in counties with a BLM non-riot protest); and the Asian CVAP shares' coefficients have inconsistent statistical significance and signs (3 negative, one positive). Some of the BLMRPT-related regressors have large coefficients but those coefficients' imprecision warns against putting undue weight on them.

D. Potential electoral impact. If the reader accepts that a regression model (whether a linear regression or a GAM) discussed in this paper properly controls for confounding 
factors, such that the model's BLM-related coefficients can be interpreted as causal effects of BLM protests, then the model may be used to infer how the 2020 election's results might have been different if the intensity of BLM protests in each county had been different.

An obvious scenario to explore is how the election results would have been different had there been no BLM protests. Applying model XVI, the most elaborate, finds a modest effect on average. Taking model XVI's estimates as causal, the mean county would have swung 0.13 percentage points less towards the Democratic Party absent BLM protests, and the standard deviation of individual counties' counterfactual changes would be 0.54 points. (The median county would have swung exactly as much as it actually did, because a narrow majority of counties experienced no BLM protests.) Aggregating to the state level, the county-level effects partially cancel each other out within states, producing less-dramatic state-level estimates: absent BLM protests, the mean non-Alaska state would have swung 0.10 percentage points less towards the Democratic Party and the median non-Alaska state 0.18 points less, with a standard deviation of 0.30 points Nonetheless, even these shifts would have tightened the final election result. Redistributing the lost Democratic votes proportionately to the Republican Party and minor parties, Joe Biden would have lost Arizona $49.02 \%$ to $49.39 \%$ instead of winning Arizona $49.36 \%$ to $49.06 \%$, thinning his Electoral College victory from 306-232 to $295-243$.

I check that result with a less ornate (and less potentially overfitted) model, model XII. Interpreting model XII's estimates as causal, the mean county would have swung 0.18 percentage points less towards the Democratic Party absent BLM protests, with a county-level standard deviation of 0.23 points. The standard deviation from model XII is far less than model XVI's because model XII assumes away racial heterogeneity in responses to BLM protests, instead taking counties' responses to be the same regardless of counties' racial composition. Aggregating to the state level, the mean non-Alaska state and median non-Alaska state would have swung 0.21 percentage points less towards the Democratic Party, with a standard deviation among states of 0.05 points. Arizona would still flip under these relatively uniform state-level changes, with Biden again expected to lose by 0.41 percentage points, or about 14,000 votes. Georgia would also flip, with Trump winning by 0.10 percentage points, or about 5000 votes, according to model XII. The loss of both states to Trump would have thinned Biden's Electoral College victory to 279-259.

To complement the no-protests scenario, I also consider a more-protests scenario: the hypothetical election result if each county had had twice its actual number and rate of BLM protests. Notably, by the estimates of models XVI and XII, the mean county would have swung less towards the Democratic Party had BLM protests been twice as intense, namely by 0.06 percentage points (with a standard deviation of 0.42 points) under model XVI and by 0.04 percentage points (with a standard deviation of 0.10 points) under model XII. In neither case would a state-level result have been overturned; the interesting feature of these results is rather that more protests might have dampened the Democratic swing, just as no protests might have.

\section{Discussion}

Since the 2020 reinvigoration of the BLM protest movement, published journalism and opinion have suggested that the movement, its protests, or its rhetoric might have harmed Joe Biden's electoral performance. As an attempt to test rigorously for that harm, this study quantifies the statistical association across space between BLM protests and presidential-election swing towards the Democratic Party, controlling for background factors.

This study's core finding is that, in models controlling aggressively for background factors (models IX-XVI), the average association between BLM protests and Democratic swing was, if anything, positive. While journalists and pundits might have expected otherwise, US counties that hosted a BLM protest in 2020 swung more towards the Democratic Party by about 0.3 or 0.4 percentage points, whether or not the protest was a riot. Inasmuch as BLM protests caused those extra county-level swings, they were powerful enough to prevent Trump from winning Arizona and possibly Georgia.

Models that include the intensity of protest (BLM protests per thousand population) as well as the presence of protest tend to find a negative association between intensity and Democratic swing, suggesting that the marginal impact of BLM protests was negative, despite the positive average association of protests with Democratic swing. There may therefore have been diminishing returns to increasing levels of protest: the first BLM protest in a county might, on average, have increased Democratic swing, but sufficiently many BLM protests might have suppressed it.

Additional models (XV and XVI) tested how the racial makeup of US counties' CVAPs moderated the association between BLM protests and Democratic swing. Media coverage posited that Latina and Latino voters might be particularly averse to BLM protests, but my models found equivocal results. Counties with relatively large "Hispanic or Latino" CVAPs had statistically similar Democratic swings to other counties after non-riot BLM protests, and showed weaker Democratic swing only after BLMassociated riots.

Such race-specific findings should be interpreted with particular caution, because they come from more-complex models prone to overfitting. More generally, all of this study's results come with the caveat that the models' standard errors are likely too small due to spatial autocorrelation (the tendency of nearby counties to show 
more similar swings than distant counties, even after controlling for all of the models' regressors), inflating the apparent statistical significance of the model's parameter estimates. The multiple-testing problem is also present. When judging the statistical significance of many parameter estimates at once, some are likely to be statistically significant by random chance alone.

Another limitation of this study is its reliance on the "stable unit treatment value assumption", or "SUTVA". The SUTVA requires that the treatment being studied (in this case, a BLM protest) has a consistent effect on the units treated (in this case, counties), and that treating one unit has no impact on the effect of treating another unit (i.e. that a BLM protest in one county has no spillover effect on other counties). In reality, it is not credible to assume that every BLM protest has the same effect on voting for Democrats; small protests plausibly have weaker effects, and this study does not use data on protest size. Fortuately, this violation of the SUTVA can be circumvented if one regards the study as estimating only the average association between BLM protests and Democratic swing. The other SUTVA requirement - the absence of spillovers - is very likely also violated, although spillover effects would tend to obscure any effect of BLM protests on voting, rather than exaggerating any such effect. Spillovers would shift some of the impact of a BLM protest in one county into adjacent or nearby counties, blurring the differences between counties with BLM protests and counties without BLM protests.

Repeating this study's analyses with different datasets could test my conclusions' robustness. For example, my analyses rely on the US Crisis Monitor's classification of protests into riots versus non-riots. Finer-grained classifications might reveal heterogeneity within either category of protest, such as police-initiated riots having different associations with Democratic swing to protester-initiated riots. Alternatively, other sources could disagree outright with US Crisis Monitor's classifications, and such alternative classifications might change my substantive findings.

Finally, my analyses are not a comprehensive assessment of BLM protests' impact. They quantify at most one local effect of individual street protests. This study is not directly informative about other aspects of the BLM movement such as the public-policy proposals it popularized ("defund the police", "abolish the police", the 8 reform measures grouped under the name "8 Can't Wait" (37), the further measures grouped under the name " 8 to Abolition" (38), and the contents of The Movement for Black Lives's 2016 policy platform (39)) or non-electoral political changes provoked by the movement.

1. Freddy Gray (28 August 2020). The Democrats' embrace of BLM may be about to monumentally backfire. The Telegraph. Available at https://www.telegraph.co.uk/ politics/2020/08/28/democrats-embrace-blm-may-monumentally-backfire/. Accessed on 28 August 2020.

2. Fiona Jones (3 November 2020). "Violent" BLM movement could lose Democrats the election, says Conservative commentator. LBC. Available at https://ww.lbc.co.uk/radio/presenters/nick-ferrari/ violent-blm-movement-will-lose-democrats-the-election/. Accessed on 17 December 2020.

3. Sabrina Tavernise, John Eligon (11 November 2020). Voters Say Black Lives Matter Protests Were Important. They Disagree On Why. The New York Times. Available at https://www. nytimes.com/2020/11/07/us/black-lives-matter-protests.html. Accessed on 17 December 2020

4. Anonymous (9 November 2020). James Clyburn says he and John Lewis feared "defund the police" would undermine Black Lives Matter movement. CBS News. Available at https://www.cbsnews.com/news/ james-clyburn-john-lewis-defund-the-police-messages-black-lives-matter/. Accessed on 17 December 2020.

5. Glenn Thrush (2 December 2020). Democrats should ditch 'defund the police' and give Ocasio-Cortez a bigger platform, Obama says. The New York Times. Available at https://www.nytimes.com/2020/12/02/us/ democrats-should-ditch-defund-the-police-and-give-ocasio-cortez-a-bigger html. Accessed on 2 December 2020.

6. Germania Rodriguez Poleo (5 November 2020). What went wrong for Biden with Latinos? The answer might be hard to swallow. The Independent. Available at https://www.independent.co.uk/voices/ florida-latino-vote-miami-dade-trump-biden-b1599637.html. Accessed on 17 December 2020.

7. Daniel Marans (23 November 2020). Why 'Defund The Police' Attacks Were So Potent Against Democrats. HuffPost UK. Available at https://www.huffingtonpost.co.uk/ entry/republicans-defund-the-police-attacks-democrats-election-2020_n_ 5 fb68698c5b695be83008c57. Accessed on 17 December 2020.

8. Lisa Mascaro (6 November 2020). House Democrats blame losses on polls, message, even Trump. Associated Press. Available at https://apnews.com/article/ election-2020-virus-outbreak-health-elections-house-elections-c95d040d079 Accessed on 17 December 2020.

9. Laura Barrón-López, Holly Otterbein (19 November 2020). Black Lives Matter activists strike back at Dems slamming 'defund the police'. Politico. Available at https://www. politico. com/news/2020/11/19/blm-defund-police-democrats-437940. Accessed on $17 \mathrm{De}$ cember 2020.

10. Eric Ting (6 November 2020). 'We will get f-ing torn apart': Nancy Pelosi, other Dems take fire on heated caucus call. San Francisco Chron icle/SFGATE. Available at https://www.sfgate.com/politics/article/ Nancy-Pelosi-Abigail-Spanberger-call-defund-police-15707741.php. Accessed on 1 April 2021.

11. Tal Axelrod (14 November 2020). Warner blames Democratic losses on 'de fund the police'. The Hill. Available at https://thehill.com/homenews/senate/ 525983-warner-blames-democratic-losses-on-defund-the-police. Accessed on 1 April 2021.

12. Beth Reinhard, Lori Rozsa (5 November 2020). Miami-Dade Hispanics helped sink Biden in Florida. The Washington Post. Available at https://www. washingtonpost.com/politics/biden-miami-dade-vote-drop/2020/11/04/ ec06f $13 \mathrm{e}-1 \mathrm{ebd}-11 \mathrm{eb}-\mathrm{ba} 21-\mathrm{f} 2 \mathrm{f} 001 \mathrm{f} 0554 \mathrm{~b} \_$story.html. Accessed on 5 November 2020.

13. Catherine Sanz (21 November 2020). Misinformation targeted Latino voters in the 2020 election. ABC News. Available at https://abcnews.go.com/Politics/ latino-voters-misinformation-targets-election-2020/story?id=74189342. ACcessed on 17 December 2020.

14. Sharif Amlani, Carlos Algara. Partisanship \& nationalization in American elections: Evidence from presidential, senatorial, \& gubernatorial elections in the U.S. counties, 1872-2020. Electoral Studies, 73, 102387 (2021).

15. Sharif Amlani, Carlos Algara (7 September 2021). Raw County-Level Vote Data for U.S. Presidential Election Outcomes, 1868-2020. Harvard Dataverse. Downloaded as dataverse_shareable_presidential_county_returns_1868_2020.Rdata via https://dataverse.harvard.edu/dataset.xhtml?persistentId=doi:10.7910/ DVN/DGUMFI. Accessed on 17 September 2021.

16. Armed Conflict Location \& Event Data Project and Bridging Divides Initiative (14 November 2020). Downloaded as USA_2020_Nov14.xlsx from https: //acleddata.com/download/ 22846/ via https://acleddata.com/special-projects/us-crisis-monitor/. Accessed on 19 November 2020

17. United States Census Bureau, Geography Bureau (9 August 2019). Current County and Equivalent National Shapefile. Available at https://www. census.gov/cgi-bin/geo/ shapefiles/index.php. Accessed on 24 November 2020.

18. United States Census Bureau (10 December 2020). 2015-2019 American Community Survey 5-Year Estimates: Selected Social Characteristcs in the United States. Downloaded as ACSDP5Y2019.DP02_2020-12-13T133641.zip from https://data.census. gov/api/access/table/download?download_id=D5pjXXYBMTOFVklekX8x via https: $/ /$ data. census . gov/cedsci/table? $q=$ United\%20States $\& g=0100000$ US $.050000 \& y=$ 2019\&d=ACS\%205-Year\%20Estimates\%20Data\%20Profiles\&tid=ACSDP5Y2019.DP02\& hidePreview=true. Accessed on 13 December 2020

19. United States Census Bureau (10 December 2020). 2015-2019 American Community Survey 5-Year Estimates: Selected Economic Characteristcs. Downloaded as ACSDP5Y2019.DP03_2020-12-13T211612.zip from https://data.census gov/api/access/table/download?download_id=pQj4XnYBMjquz7b8hVrB via https://data. census.gov/cedsci/table?q=United\%20States\&g=0100000uS . 050000\&y=2019\&tid=ACSDP5Y2019. DP03\&hidePreview=true. Accessed on $14 \mathrm{De}$ cember 2020.

20. United States Census Bureau (10 December 2020). 2015-2019 American Community Survey 5-Year Estimates: Age and Sex. Downloaded as ACSST5Y2019.S0101_2020-12-15T141952.zip from https://data.census.gov/ api/access/table/download?download_id=mLPYZnYB3GZcT2nNG4EN via https: 
$/ /$ data . census . gov/cedsci/table? $q=a g e \& g=0100000$ US $.050000 \& y=2019 \& d=A C S \%$ 205-Year\%20Estimates\%20Subject\%20Tables\&tid=ACSST5Y2019. S0101\&tp=true\& hidePreview=true. Accessed on 15 December 2020.

21. United States Census Bureau, Redistricting \& Voting Rights Data Office (19 February 2021). Citizen Voting Age Population (CVAP) Special Tabulation From the 2015-2019 5-Year American Community Survey. Downloaded from https://www2. census.gov/programs-surveys/decennial/rdo/datasets/2019/2019-cvap/CVAP_ 2015-2019_ACS_csv_files.zip via https://www.census.gov/programs-surveys/ decennial-census/about/voting-rights/cvap.2019.html. Accessed on 31 March 2021.

22. United States Census Bureau (16 September 2021). 2020 Decennial Census PL 94-171 Redistricting Data: Race. Downloaded as DECENNIALPL2020.P1_2021-09-18T065621.zip from https://data.census.gov/api/access/table/download?download_id= 90f08341ac1c55b2821f38fdf08e99b03f95d349fe12d45cf19202cfc7205ebc via https : //data. census. gov/cedsci/table? $\mathrm{g}=0100000$ US\% $240500000 \& \mathrm{y}=2020 \& \mathrm{tid}=$ DECENNIALPL2020. P1\&t $p=$ true\&hidePreview $=$ false. Accessed on 18 September 2021.

23. Bureau of Economic Analysis. Per capita personal income (Dollars); table CAINC1. Downloaded as download.csv from https://apps.bea.gov/iTable/download.cfm via https://apps.bea.gov/iTable/iTable.cfm?reqid=70\&step=1\&isuri=1\&acrdn= $6 \#$ reqid $=70 \&$ step $=1 \&$ isur $i=1 \&$ acrdn $=6$. Accessed on 11 January 2022.

24. Bureau of Labor Statistics. Local Area Unemployment Statistics; Labor force data by county, not seasonally adjusted, December 2019-January 2021(p). Downloaded from https : //www . bls.gov/web/metro/laucntycur14.txt via https://www.bls.gov/lau/tables.htm. Accessed on 3 April 2021.

25. C Grammich, K Hadaway, R Houseal, D E Jones, A Krindatch, R Stanley, R H Taylor (11 December 2018). U.S. Religion Census: Religious Congregations and Membership Study, 2010 (County File). Downloaded via https://www.thearda.com/Archive/Files/Downloads/ RCMSCY10_DL2.asp. Accessed on 16 December 2020.

26. Center for Systems Science and Engineering, Johns Hopkins University (13 December 2020). COVID-19 Data Repository. Available at https://github.com/CSSEGISandData/ COVID-19/tree/master/csse_covid_19_data/csse_covid_19_time_series. Accessed on 14 December 2020.

27. Mapping Police Violence (31 January 2021). 2013-2020 Police Killings. Downloaded from https://static1.squarespace.com/static/54ecf211e4b0ed744420c5b6/ t/60170e083bc1b048412bd73c/1612123675216/MPVDatasetDownload.xlsx via https://mappingpoliceviolence.org/s/MPVDatasetDownload.xlsx. Accessed on 7 February 2021.

28. United States Census Bureau (2010). 2010 ZCTA to County Relationship File. Downloaded from http://www2.census.gov/geo/docs/maps-data/data/rel/zcta county_rel_10.txt via https://www.census.gov/geographies/reference-files/ 2010/geo/relationship-files.html\#par_textimage_674173622. Accessed on 7 February 2021.

29. Defense Casualty Analysis System, Defense Manpower Data Center (17 September 2021). Operation Enduring Freedom (OEF) Names of Fallen. Downloaded as OEFNames via https : //dcas.dmdc.osd.mil/dcas/pages/report_oef_namesalp.xhtml. Accessed on 19 September 2021

30. Defense Casualty Analysis System, Defense Manpower Data Center (17 September 2021). Operation Iraqi Freedom (OIF) Names of Fallen. Downloaded as OIFNames via https: //dcas.dmdc.osd.mil/dcas/pages/report_oif_namesalp.xhtml. Accessed on 19 September 2021

31. Defense Casualty Analysis System, Defense Manpower Data Center (17 September 2021). Operation New Dawn (OND) Names of Fallen. Downloaded as ONDNames via https: //dcas. dmdc.osd.mil/dcas/pages/report_ond_namesalp.xhtml. Accessed on 19 September 2021.

32. Defense Casualty Analysis System, Defense Manpower Data Center (17 September 2021). Operation Inherent Resolve (OIR) Names of Fallen. Downloaded as OIRNames via https: //dcas.dmdc.osd.mil/dcas/pages/report_oir_namesalp.xhtml. Accessed on 19 September 2021.

33. Defense Casualty Analysis System, Defense Manpower Data Center (17 September 2021). Operation Freedom's Sentinel (OFS) Names of Fallen. Downloaded as OFSNames via https: //dcas.dmdc.osd.mil/dcas/pages/report_ofs_namesalp.xhtml. Accessed on 19 September 2021

34. Grace Panetta (4 September 2020). Voting in the 2020 presidential election officially starts today as North Carolina sends out over 600,000 mail ballots. Business Insider. Available at https://www.businessinsider.com/ 2020-election-voting-begins-september-4-north-carolina-mails-ballots-2020-9. Accessed on 31 March 2021.

35. Joey Garrison (22 August 2020). Voting starts earlier than you might realize. It has Trump battling the clock in some battleground states. USA Today. Available at https://eu.usatoday.com/story/news/politics/elections/2020/08/22/ voting-starts-earlier-than-you-might-realize-has-trump-battling-clock-some-battleground-states/ 3298789001/. Accessed on 31 March 2021

36. Anonymous (14 August 2020). Absentee by mail voting in North Carolina: What you need to know. ABC11 Raleigh-Durham. Available at https://abc11.com/ absentee-ballot-nc-voting-request-north-carolina/6365463/. Accessed on 31 March 2021.

37. Campaign Zero. 8 Can't Wait. Available at https://8cantwait.org/. Accessed on 24 February 2021.

38. Mon Mohapatra, Leila Raven, Nnennaya Amuchie, Reina Sultan, K Agbebiyi, Sarah T Hamid, Micah Herskind, Derecka Purnell, Eli Dru, Rachel Kuo. 8 to Abolition. Available at https //www . 8toabolition. com/. Accessed on 11 March 2021.

39. The Movement for Black Lives. Platform. Defunct webpage archived at https://web. archive.org/web/20160801231434/https://policy.m4bl.org/platform/. Archived on 1 August 2016, accessed on 25 July 2021. 